\title{
HUBUNGAN ANTARA SUHU, pH DAN BERBAGAI VARIASI JARAK DENGAN KADAR TIMBAL (Pb) PADA BADAN AIR SUNGAI ROMPANG DAN AIR SUMUR GALI INDUSTRI BATIK SOKARAJA TENGAH TAHUN 2016
}

\author{
Ami Sukoasih 1), Teguh Widiyanto, ${ }^{2)}$, Suparmin, ${ }^{3)}$ \\ Jurusan Kesehatan Lingkungan, Politeknik Kesehatan Kemenkes Semarang, \\ Jl.Raya Baturaden KM 12 Purwokerto, Indonesia
}

\begin{abstract}
Abstrak
Batik merupakan komoditas yang saat ini sedang berkembang pesat. Seiring dengan berkembangnya industri batik, meningkat pula volume limbah cair yang dihasilkan. Limbah cair batik yang dibuang ke lingkungan tanpa dilakukan pengolahan dapat mencemari badan air dan sumur gali penduduk sekitarnya. Limbah cair industri batik mengandung logam berat seperti timbal, besi, seng, krom, tembaga dan kadmium. Dampak timbal (Pb) bagi kesehatan manusia dapat menimbulkan keracunan pada saraf. Tujuan penelitian untuk mengetahui suhu, pH dan berbagai variasi jarak dengan kadar Pb pada badan air Sungai Rompang dan air sumur gali disekitar industri batik Sokaraja Tengah. Jenis penelitian observasional dengan design crossectional. Hasil penelitian dengan menggunakan analisis statistik uji Regresi Linier Sederhana menunjukan bahwa tidak ada hubungan antara suhu dengan kadar Pb $(p=0,085)$, tidak ada hubungan antara $\mathrm{pH}$ dengan kadar $\mathrm{Pb}(p=0,193)$, tidak ada hubungan antara jarak dengan kadar $\mathrm{Pb}(p=0,060)$. Untuk hasil suhu, $p H$ dan jarak titik sampling pada badan air Sungai Rompang dengan kadar timbal $(\mathrm{Pb})$ masih dibawah nilai ambang batas menurut PP No.82 tahun 2001 tentang Pengelolaan Kualitas Air dan Pengendalian Pencemaran Air yaitu 0,014 mg/l. Disimpulkan bahwa tidak ada hubungan antara suhu, ph dan jarak dengan kadar Pb pada sumur gali dan nilai kadar Pb masih dibawah nilai ambang batas menurut Permenkes No. 416/ Menkes/ IX/ 1990 tentang Persyaratan Kualitas Air Bersih. Sedangkan untuk kadar Pb pada badan air juga masih dibawah nilai ambang batas. Perlunya mengolah limbah cair batik sebelum dibuang ke lingkungan, Sebaiknya masyarakat tidak menggunakan sumber air bersih yang tercemar timbal $(\mathrm{Pb})$.
\end{abstract}

Kata kunci : Suhu, pH, Jarak, Kadar Timbal (Pb), Badan Air, Sumur Gali

\begin{abstract}
[The Correlation of Temperature, Ph and Some Varieties of Distance with Lead (Pb) Level on Water Body Rompang River and Drilled Wells Batik Central Sokaraja Industries Year 2016] Batik is a commodity which develops rapidly nowadays. Along with the batik development, the volume of waste water is increasing as well. Batik's waste water which was thrown to environment without any treatment can contaminate water body and people's drilled wells around there. Batik's waste water contains heavy metals such as lead, metal, zinc, chrome, copper and cadmium. Lead (Pb) effect can cause poisonous of nerve. The purpose of this research is to find out temperature, $p H$ and some varieties of distance with lead $(\mathrm{Pb})$ level on water body Rompang River and drilled wells around the industries of batik Central Sokaraja. This type of research is observational with cross sectional design. The result of this research used statistics analysis Simple Linier Regression test shows that there were no correlation between temperature and Pb level ( $p=0,085)$, no correlation between $\mathrm{pH}$ and $\mathrm{Pb}$ level $(p=0,193)$, no correlation between distance and $\mathrm{Pb}$ level $(p=0,060)$. For the result of temperature, $\mathrm{pH}$ and distance of the sampling on water body Rompang River with lead $(\mathrm{Pb})$ level is still under the threshold value based on PP No.82 year 2001 about Management of Water Quality and Control of Water Contamination that is $0,014 \mathrm{mg} / \mathrm{l}$. It can be concluded that there was no correlation between temperature, $\mathrm{pH}$ and istance with $\mathrm{Pb}$ level on drilled water and $\mathrm{Pb}$ level was still under the threshold value based on Permenkes No.416/Menkes/IX/1990 about Requirements of Clear Water Quality. Whereas, Pb level on water body was still under the threshold value. Batik waste water treatment is needed before it is thrown to the environment. People should not use clear water source which is contaminated by lead $(\mathrm{Pb})$.
\end{abstract}

Keywords: Temperature, pH, Distance, Lead $(\mathrm{Pb})$ level, Water Body, Drilled Well

\footnotetext{
1) E-mail: sukoasiha@yahoo.com

${ }^{2)}$ E-mail: teguhwidiyanto007@gmail.com

${ }^{3)}$ E-mail: pakparmin@yahoo.com
} 


\section{PENDAHULUAN}

Air merupakan salah satu sumber daya alam yang memiliki fungsi sangat penting bagi kehidupan dan perikehidupan manusia, serta untuk memajukan kesejahteraan umum, sehingga merupakan modal dasar dan faktor utama pembangunan (PP No 82 Tahun 2001). Sejalan dengan perkembangan penduduk dunia serta perkembangan industri yang sangat pesat, maka banyak sumber-sumber air yang mulai tercemar oleh limbah domestik maupun limbah industri (Nusa Idaman S, 2002, h.1).

Salah satu contoh permasalahan air limbah yaitu pada industri batik. Batik merupakan komoditas yang saat ini sedang berkembang pesat. Batik sekarang telah menjadi tren mode di semua kalangan sehingga membuat para pengrajin batik semakin semangat mengembangkan produknya. Seiring dengan berkembangnya industri batik, meningkat pula volume limbah cair yang dihasilkannya. Limbah cair industri batik dilaporkan mengandung logam berat seperti timbal, besi, seng, krom, tembaga dan kadmium (I.Hartati,dkk,2011). Masuknya logam berat (timbal) ke badan air yang diakibatkan oleh limbah cair batik dapat mempengaruhi kualitas air.

Kadar $\mathrm{Pb}$ pada air dipengaruhi oleh suhu dan $\mathrm{pH}$, pada suhu yang tinggi senyawa logam berat akan larut dalam air dan pada $\mathrm{pH}$ rendah kelarutan logam berat akan lebih tinggi sehingga akan menyebabkan toksisitas logam berat semakin besar.

Dampak timbal $(\mathrm{Pb})$ bagi kesehatan manusia dapat menimbulkan keracunan pada saraf. Pada anak-anak dapat menyebabkan kerusakan jaringan saraf otak, anemia, dan kelumpuhan (Soeparman\&Suparmin, 2002).

Penelitian yang dilakukan oleh Esti Nugraheni pada tahun 2015 bahwa kadar $\mathrm{Pb}$ dalam limbah cair industri batik dapat mencapai 3,668 $\mathrm{mg} / \mathrm{L}$ dimana kadar timbal masih di atas baku mutu menurut PP No 82 / 2001 yaitu sebesar 0,03 mg/L.

Hasil pemeriksaan pendahuluan yang dilakukan oleh peneliti pada bulan Januari 2016 bahwa kadar $\mathrm{Pb}$ dalam air sungai disekitar tempat pembuangan limbah batik Sokaraja Tengah sebesar $1,9 \mathrm{mg} / \mathrm{L}$, kandungan $\mathrm{Pb}$ pada air sungai tersebut melebihi batas maksimum baku mutu yaitu $1,0 \mathrm{mg} / \mathrm{L}$ (Perda Jateng No 05/2015 Golongan baku mutu II) dan pada jarak \pm 10 meter $\mathrm{Pb}$ sumur gali sebesar $1,5 \mathrm{mg} / \mathrm{L}$, kandungan $\mathrm{Pb}$ pada air sumur gali tersebut melebihi batas maksimum baku mutu yaitu $0,05 \mathrm{mg} / \mathrm{L}$ (Permenkes RI No 416/1990), dengan demikian peneliti ingin mengetahui beberapa hal yaitu apakah ada hubungan antara suhu, $\mathrm{pH}$ dan berbagai variasi jarak dengan kadar timbal $(\mathrm{Pb})$ pada badan air sungai
Rompang dan air sumur gali industri batik Sokaraja Tengah.

Tujuan dalam penelitian ini yaitu suhu, $\mathrm{pH}$ dan berbagai variasi jarak dengan kadar $\mathrm{Pb}$ pada badan air Sungai Rompang dan air sumur gali disekitar industri batik Sokaraja Tengah.

\section{BAHAN DAN METODE}

Variabel independen dalam penelitian ini yaitu suhu, $\mathrm{pH}$ dan berbagai variasi jarak dan variabel dependen yaitu kadar $\mathrm{Pb}$ badan air Sungai Rompang dan air sumur gali disekitar pemukiman industri batik sedangkan variabel pengganggunya yaitu debit air sungai, curah hujan, dan jenis tanah serta variabel perantaranya yaitu kontruksi sumur. Jenis penelitian ini adalah observasional dengan design crossectional.

Populasi dalam penelitian ini yaitu seluruh air sungai dan air sumur gali di sekitar industri batik Desa Sokaraja Tengah. Sedangkan untuk pengambilan sampelnya menggunakan metode purposive sampling. Purposive sampling yaitu penetuan sampel dengan kriteria tertentu yang sebelumnya ditetapkan oleh peneliti. Kriteria sampel meliputi kriteria inklusi dan kriteria eksklusi, dimana kriteria tersebut menentukan dapat atau tidaknya sampel digunakan. Berdasarkan kriteria tersebut maka sampel yang diambil dalam penelitian ini yaitu 9 sampel dari 9 sumur gali dan untuk badan air diambil 3 titik pengambilan sampel yaitu pada bagian hulu, titik pencemaran dan bagian hilir.

Data diperloleh dengan cara observasi, pengambilan sampel, pemeriksaan sampel di laboratorium dan dokumentasi. Instrument yang digunakan berupa checklist, alat laboratorium untuk pemeriksaan timbal, roll meter, thermometer suhu, pH meter, botol timba dan wadah air sampel.

Analisis data yang digunakan Uji Regresi Linier Sederhana.

\section{III.HASIL DAN PEMBAHASAN \\ Gambaran Umum Wilayah}

Topografi wilayah Desa Sokaraja Tengah merupakan wilayah dengan satuan gemorfologi dengan bentuk permukaan berelief halus, kemiringan tanah $0^{\circ}$, memiliki warna tanah merah dengan tekstur tanah lempung. Jenis tanah lempung memiliki nilai porositas yang lebih besar dan permeabilitas yang lebih kecil.

Sumber air bersih mayoritas warga Desa Sokaraja menggunakan sumur gali. Air sumur gali digunakan oleh warga untuk kebutuhan sehari-hari seperti untuk minum, memasak, mandi, dll. Jumlah industri batik Desa Sokaraja Tengah sebanyak 25 industri. Industri batik menghasilkan limbah cair 
dari proses medel. Medel adalah proses pencelupan kain yang sudah dibatik ke cairan warna secara berulang-ulang sehingga mendapatkan warna yang diinginkan. Bahan-bahan yang digunakan untuk pembuatan batik berasal dari bahan kimia.

\section{Curah Hujan dan Debit Air Sungai}

Berdasarkan data curah hujan dari Unit SDA-BM Wilayah Sokaraja Kabupaten Banyumas selama bulan Mei 2016 jumlah hujannya sebesar 298 mm dan banyaknya hari hujan yaitu 15 hari. Hujan yang tinggi juga akan mempengaruhi debit air sungai semakin tinggi. Hasil pengukuran debit di lokasi penelitian dari tiga titik pengambailan sampel diperoleh rata-rata debit air sungai sebesar 278 1/det.

Curah hujan di suatu daerah akan menentukan volume dari badan air dalam rangka mempertahankan efek pencemaran terhadap setiap bahan buangan di dalamnya (deluting effects). Curah hujan yang cukup tinggi sepanjang musim dapat lebih mengencerkan (mendispersikan air yang tercemar).

Effendi (2003) menyatakan bahwa dengan meningkatnya debit, kadar bahan-bahan alam yang terlarut ke suatu badan air akibat erosi meningkat secara eksponensial. Namun, konsentrasi bahanbahan antropogenik yang memasukin badan air tersebut mengalami penurunan karena terjadi proses pengenceran. Jika suatu bahan pencemar masuk ke badan air dengan kecepatan konstan, kadar bahan pencemar dapat ditentukan dengan membagi jumlah bahan pencemar yang masuk dengan debit badan air.

\section{Jenis Tanah}

Berdasarkan data dari Desa Sokaraja tengah, tekstur tanah Desa Sokaraja Tengah yaitu lempung. Robert J (1996), bilamana suatu material tanah didominasi oleh lempung, maka struktur dari tanah itu menjadi masalah yang penting. Struktur ini tergantung dari penyusunan partikel-partikel lempung. Berdasarkan jenis ion yang terserap ke lempung tersebut, partikel-partikel dapat menyebar (dispersed) secara individual atau dapat menyatu (flocculated) membentuk kumpulan-kumpulan partikel lempung dan satuan-satuan struktur (soil aggregates) yang berukuran kurang lebih beberapa millimeter. Lempung mempunyai porositas tinggi tetapi permeabilitasnya rendah karena ruangruangnya sangat kecil.

\section{Hasil Pengamatan Terhadap Sumur Gali}

Hasil pengamatan terhadap sumur gali bahwa jumlah sumur gali yang dijadikan sampel sebanyak 9 sumur gali. Dari 9 sumur gali tersebut bila di hitung dari hasil inspeksi sanitasi memenuhi syarat semua, tetapi apabila diperjelas dari karakteristik sumur gali ada 6 sumur gali yang tidak memenuhi syarat.

Hasil pengamatan secara umum terhadap sumur gali sampel menunjukan bahwa karakteristik sumur gali yaitu dinding memenuhi syarat ada 8 SGL (89\%) dan tidak memenuhi syarat 1 SGL (11\%), penggunaan alat pengambilan air semua memenuhi syarat, lantai sumur memenuhi syarat ada $6(86 \%)$ dan tidak memenuhi syarat $3(14 \%)$, SPAL dan jarak sumur dari sumber pencemaran memenuhi syarat 8 (89\%) dan tidak memenuhi syarat $1(11 \%)$.

Sumur gali adalah satu konstruksi sumur yang paling umum dan meluas dipergunakan untuk mengambil air tanah bagi masyarakat kecil dan rumah - rumah perorangan sebagai air minum dengan kedalaman 7-10 meter dari permukaan tanah. Sumur gali menyediakan air yang berasal dari lapisan tanah yang relatif dekat dari permukaan tanah, oleh karena itu dengan mudah terkena kontaminasi melalui rembesan. Keadaan konstruksi dan cara pengambilan air sumur pun dapat menjadi sumber kontaminasi, misalnya sumur dengan konstruksi terbuka dan pengambilan air dengan timba. Sumur dianggap mempunyai tingkat perlindungan sanitasi yang baik, bila tidak terdapat kontak langsung antara manusia dengan air di dalam sumur. Sumur gali ada yang memakai dinding sumur dan ada yang tidak memiliki dinding sumur. Syarat konstruksi pada sumur gali meliputi dinding sumur, bibir sumur, lantai sumur, serta jarak dengan sumber pencemar (Gabriel, 2001).

Sumur gali yang tercemar oleh logam berat khusunya timbal sebaiknya tidak digunakan untuk kebutuhan sehari-hari. Karena keracunan timbal akan menimbulkan gangguan sistem hemopoitek (anemia), gangguan sistem saraf pusat (ensefalopati) dan perifer, kerusakan ginjal, gangguan sistem gastrointestinal (kolik, konstipasi), sistem kardiovaskuler, gangguan sistem reproduksi, gangguan fungsi pada kelenjar adrenal dan tiroid.

Air sumur gali yang mengandung logam berat timbal $(\mathrm{Pb})$ dapat diturunkan menggunakan abu sekam padi. Menurut penelitian yang dilakukan oleh Dyah Kristiyanti, dkk bahwa proses adsorpsi menggunakan zeolit abu sekam padi dapat menurunkan konsentrasi logam $\mathrm{Pb}$ pada air sumur sebesar $72,78 \%$.

Pengukuran Suhu Badan Air Sungai Rompang

Hasil pengukuran suhu pada badan air sungai Rompang dapat dilihat pada tabel 1 sebagai berikut : 
Tabel 1: Hasil Pengukuran Suhu Badan Air Sungai Rompang

\begin{tabular}{cccc}
\hline $\begin{array}{c}\text { Nama } \\
\text { Sampel }\end{array}$ & Suhu $\left({ }^{\mathbf{0}} \mathbf{C}\right)$ & $\begin{array}{c}\text { Kadar } \\
\mathbf{P b} \\
(\mathbf{m g} / \mathbf{l})\end{array}$ \\
\cline { 1 - 2 } & Air & Udara & \\
\cline { 2 - 3 } ABS 1 & 28 & 32 & 0,014 \\
$\begin{array}{c}\text { (Hulu) } \\
\text { BBS 2 (Titik }\end{array}$ & 28 & 30 & 0,014 \\
$\begin{array}{c}\text { Pencemaran) } \\
\text { CBS 3 } \\
\text { (Hilir) }\end{array}$ & 28 & 32 & 0,014 \\
\hline Rata-rata & 28 & 31,3 & 0,014
\end{tabular}

Nilai suhu dan kadar $\mathrm{Pb}$ tersebut masih memenuhi syarat menurut Peraturan Pemerintah Nomor 82 Tahun 2001 Tentang Pengelolaan Kualitas Air dan Pengendalian Pencemaran Air yaitu untuk kadar $\mathrm{Pb}$ yang diperbolehkan maksimal $0,03 \mathrm{mg} / \mathrm{l}$.

Sorense (1991) dalam Fauziah (2012) menyatakan bahwa peningkatan suhu perairan cenderung menaikkan akumulasi dan toksisitas logam berat, hal ini terjadi karena meningkatnya laju metabolisme dari organisme air. Sarjono (2009), kenaikan suhu tidak hanya akan meningkatkan metabolisme biota perairan, namun juga dapat meningkatkan toksisitas logam berat diperairan (http://etheses.uin-malang.ac.id). Suhu mempengaruhi konsentrasi logam berat di kolom air dan sedimen, kenaikan suhu air yang lebih dingin akan memudahkan logam berat mengendap ke sedimen. Sementara suhu yang tinggi, senyawa logam berat akan larut di air.

Pengukuran pH Badan Air Sungai Rompang

Hasil pengukuran $\mathrm{pH}$ pada badan air sungai Rompang dapat dilihat pada tabel 2 sebagai berikut

Tabel 2: Hasil Pengukuran pH Badan Air Sungai Rompang

\begin{tabular}{ccc}
\hline Nama Sampel & $\mathbf{p H}$ & $\begin{array}{c}\text { Kadar Pb } \\
(\mathbf{m g} / \mathbf{l})\end{array}$ \\
\hline ABS 1 (Hulu) & 8,8 & 0,014 \\
BBS 2 (Titik & 8,8 & 0,014 \\
Pencemaran) & & \\
CBS 3 (Hilir) & 8,8 & 0,014 \\
\hline Rata-rata & 8,8 & 0,014 \\
\hline
\end{tabular}

Nilai $\mathrm{pH}$ dan kadar $\mathrm{Pb}$ tersebut masih berada di dalam kisaran Peraturan Pemerintah Nomor 82 Tahun 2001 Tentang Pengelolaan Kualitas Air dan Pengendalian Pencemaran Air. pH yang diperbolehkan yaitu 6-9 sedangkan kadar $\mathrm{Pb}$ yang diperbolehkan maksimal $0,03 \mathrm{mg} / \mathrm{l}$.

Palar (1994) menyatakan bahwa badan perairan yang mempunyai derajat keasaman $(\mathrm{pH})$ mendekati normal atau pada daerah kisaran $\mathrm{pH} 7$ sampai 8 , kelarutan dari senyawa-senyawa ini cenderung untuk stabil. Kenaikan $\mathrm{pH}$ pada badan perairan biasanya akan diikuti dengan semakin kecilnya kelarutan dari senyawa-senyawa logam tersebut.

Hart (1982) dalam Suwarsito dan Esti Sarjanti (2014) pada kondisi pH mendekati normal (7-8), kelarutan logam berat cenderung stabil dan akan berikatan dengan anion, sehingga logam berat akan membentuk kompleks organologam (bentuk logam organik dan logam anorganik) yang cenderung mengendap di dasar perairan (http://geoedukasi.ump.ac.id/).

Pengukuran Jarak Titik Sampling pada Badan Air Sungai Rompang

Hasil pengukuran jarak titik sampling pada badan air Sungai Rompang dapat dilihat pada tabel 3 sebagai berikut :

Tabel 3: Hasil Pengukuran Jarak Titik Sampling Badan Air Sungai Rompang

\begin{tabular}{ccc}
\hline Nama Sampel & $\begin{array}{c}\text { Jarak } \\
\text { (meter) }\end{array}$ & Hasil (mg/l) \\
\hline ABS 1 (Hulu) & 50 & 0,014 \\
BBS 2 (Titik & 0 & 0,014 \\
Pencemaran) & & \\
CBS 3 (Hilir) & 50 & 0,014 \\
\hline
\end{tabular}

Berdasarkan hasil penelitian menunjukan bahwa pada bagian hulu (ABS 1) kadar Pb sebesar $0,014 \mathrm{mg} / \mathrm{l}$ sedangkan pada titik pencemaran (BBS 2) kadar $\mathrm{Pb}$ sebesar $0,014 \mathrm{mg} / \mathrm{l}$ dan pada hilir (CBS 3) kadar $\mathrm{Pb}$ sebesar 0,014 mg/l. Pada jarak titik pencemaran dan bagian hulu, hilir tidak ada perbedaan nilai kadar $\mathrm{Pb}$ pada badan air. Hal ini dipengaruhi oleh beberapa faktor yang mempengaruhi nilai kadar $\mathrm{Pb}$ pada badan air diantaranya adalah curah hujan, debit air sungai. Semakin tinggi curah hujan, semakin tinggi pula debit air sungai sehingga kadar $\mathrm{Pb}$ dengan mudah akan terbawa oleh arus atau logam $\mathrm{Pb}$ akan terbawa secara luas ke berbagai tempat.

Kecepatan arus suatu badan air sangat berpengaruh terhadap kemampuan badan air tersebut untuk mengasimilasi dan mengangkut bahan pencemar. Pengetahuan akan kecepatan arus digunakan untuk memperkirakan kapan bahan pencemar akan mencapai suatu lokasi tertentu 
apabila bagian hulu suatu badan air akan mengalami pencemaran.

Pengukuran Kadar Timbal (Pb) pada Air Sumur Gali Di Sekitar Sungai Rompang

Hasil pengukuran kadar timbal $(\mathrm{Pb})$ pada air sumur gali di sekitar Sungai Rompang dapat dilihat pada tabel 4 sebagai berikut :

Tabel 4 : Hasil Pengukuran Kadar Timbal $(\mathrm{Pb})$ pada Air Sumur Gali Di Sekitar Sungai Rompang

\begin{tabular}{ccc}
\hline Nama Sampel & $\begin{array}{c}\text { Hasil } \\
\text { (mg/l) }\end{array}$ & $\begin{array}{c}\text { Kadar Maksimal } \\
\text { yang } \\
\text { Diperbolehkan } \\
\text { (mg/l) }\end{array}$ \\
\hline ASG 1 & 0,008 & \\
ASG 2 & 0,008 & \\
ASG 3 & 0,009 & \\
BSG 1 & 0,009 & \\
BSG 2 & 0,009 & 0,05 \\
BSG 3 & 0,009 & \\
CSG 1 & 0,008 & \\
CSG 2 & 0,009 & \\
CSG 3 & 0,009 & \\
Rata-rata & 0,0086 & \\
\hline \multicolumn{2}{c}{ Air } & sumur gali di sekitar Sungai
\end{tabular}

Rompang masih memenuhi persyaratan sebagai air bersih menurut Peraturan Menteri Kesehatan No. 416/ Menkes/ IX/ 1990 tentang Persyaratan Kualitas Air Bersih . Nilai ambang batas kadar $\mathrm{Pb}$ yang diperbolehkan maksimal 0,05 $\mathrm{mg} / \mathrm{l}$.

Timbal $(\mathrm{Pb})$ pada perairan ditemukan dalam bentuk terlarut atau tersuspensi. Kelarutan timbal cukup rendah sehingga kadar di dalam air relatif sedikit. Selain dipengaruhi oleh $\mathrm{pH}$, kadar dan toksisitas timbal juga dipengaruhi oleh kesadahan, alkalinitas, dan kadar oksigen (Hefni Efendi, 2003, h.189).

Pengukuran Suhu dan Uji Statistik Air Sumur Gali Di Sekitar Sungai Rompang

Hasil pengukuran suhu dan uji statistik pada air sumur gali di sekitar Sungai Rompang dapat dilihat pada tabel 5 dan 6 sebagai berikut :

Tabel 5 : Hasil Pengukuran Suhu pada Air Sumur Gali Di Sekitar Sungai Rompang

\begin{tabular}{ccc}
\hline \multirow{2}{*}{ Nama } & \multicolumn{2}{c}{ Suhu $\left({ }^{\circ} \mathbf{C}\right)$} \\
\cline { 2 - 3 } Sampel & Air & Udara \\
\hline ASG 1 & 28 & 31 \\
ASG 2 & 31 & 30 \\
ASG 3 & 28 & 34 \\
BSG 1 & 29 & 28,5 \\
BSG 2 & 28 & 31 \\
BSG 3 & 29 & 31
\end{tabular}

\begin{tabular}{ccc} 
CSG 1 & 29 & 31 \\
CSG 2 & 28 & 31 \\
CSG 3 & 28 & 31 \\
\hline Rata-rata & 28,7 & 30,9
\end{tabular}

Tabel 6 : Hasil Uji Statistik Suhu dengan Kadar Pb pada Air Sumur Gali Di Sekitar Sungai Rompang

\begin{tabular}{|c|c|c|c|c|c|}
\hline $\begin{array}{l}\text { Varia } \\
\text { bel }\end{array}$ & $\begin{array}{l}\text { Signifi } \\
\text { kan }\end{array}$ & $\mathbf{R}$ & $\begin{array}{l}\mathbf{R} \\
\text { square }\end{array}$ & $\begin{array}{l}\text { Kons } \\
\text { tanta }\end{array}$ & B \\
\hline Suhu & 0,085 & 0,500 & 0,250 & 0,016 & 0,000 \\
\hline
\end{tabular}
menunjukan bahwa rata-rata kadar $\mathrm{Pb}$ air sumur gali di lokasi penelitian sebesar $0,0086 \mathrm{mg} / \mathrm{l}$ dengan suhu air rata-rata sebesar $28,7{ }^{\circ} \mathrm{C}$ dan suhu udara rata-rata sebesar $30,9{ }^{\circ} \mathrm{C}$. Kadar $\mathrm{Pb}$ air sumur gali tersebut masih dibawah nilai ambang batas untuk standar menurut Permenkes No. 416 Tahun 1990 tentang persyaratan kualitas air bersih. Sedangkan suhu air dilokasi penelitian masuk dalam kategori suhu normal, dikarenakan batas standar suhu air adalah \pm 3 dari suhu udara menurut Permenkes No. 416 tahun 1990 tentang kualitas air bersih.

Tabel 6 menunjukan tingkat signifikan sebesar $0,085>\alpha(0,05)$, maka Ho diterima dan Ha ditolak. Jadi dapat dikatakan tidak ada hubungan suhu dengan kadar $\mathrm{Pb}$ pada air sumur gali. Sedangkan besarnya pengaruh suhu terhadap kadar $\mathrm{Pb}$ pada air sumur gali sebesar $25 \%$ dan sisanya 75 $\%$ dijelaskan oleh sebab-sebab lain.

Arief Happy R, dkk (Hutagalung, 1984) mengatakan bahwa kenaikan suhu tidak hanya akan meningkatkan metabolisme biota perairan, namun juga dapat meningkatkan toksisitas logam berat diperairan. Fardiaz (1992) menyatakan bahwa kenaikan suhu air akan menimbulkan beberapa akibat sebagai berikut : jumlah oksigen terlarut di dalam air menurun, kecepatan reaksi kimia meningkat, kehidupan ikan dan hewan lainnya terganggu, jika batas suhu yang mematikan terlampaui, ikan dan hewan air lainnya mungkin akan mati.

Kusumastanto (2004) mengatakan dari sejumlah penelitian yang telah dilakukan menunjukan bahwa konsentrasi logam berat terakumulasi dengan bertambahnya atau meningkatnya suhu lingkungan, yang berakibat partikel logam berat bergerak lebih cepat sehingga lebih cepat terakumulasi (http://etheses.uinmalang.ac.id).

Pengukuran pH dan Uji Statistik Air Sumur Gali Di Sekitar Sungai Rompang 
Hasil pengukuran $\mathrm{pH}$ dan uji statistik pada air sumur gali di sekitar Sungai Rompang dapat dilihat pada tabel 7 dan 8 sebagai berikut :

Tabel 7 : Hasil Pengukuran pH pada Air Sumur Gali Di Sekitar Sungai Rompang

\begin{tabular}{ccc}
\hline Nama Sampel & $\mathbf{p H}$ & $\begin{array}{c}\text { Standar yang } \\
\text { Diperbolehkan }\end{array}$ \\
\hline ASG 1 & 7,7 & \\
ASG 2 & 7,9 & \\
ASG 3 & 7,7 & \\
BSG 1 & 8,5 & \\
BSG 2 & 8,1 & $6,5-9,0$ \\
BSG 3 & 7,9 & \\
CSG 1 & 8,1 & \\
CSG 2 & 8 & \\
CSG 3 & 8,2 & \\
\hline Rata-rata & 8,01 & \\
& & \\
\hline
\end{tabular}

Tabel 8 : Hasil Uji Statistik pH dengan Kadar Pb pada Air Sumur Gali Di Sekitar Sungai Rompang

\begin{tabular}{llllll}
\hline Variabel & $\begin{array}{l}\text { Signif } \\
\text { ikan }\end{array}$ & $\mathbf{R}$ & $\begin{array}{l}\text { R } \\
\text { squar } \\
\boldsymbol{e}\end{array}$ & $\begin{array}{l}\text { Kons } \\
\text { tanta }\end{array}$ & $\mathbf{B}$ \\
\hline $\mathrm{pH}$ & 0,193 & 0,330 & 0,109 & 0,003 & 0,001 \\
\hline
\end{tabular}

Berdasarkan hasil pengukuran $\mathrm{pH}$ pada air sumur gali di lokasi penelitian diperoleh $\mathrm{pH}$ rata-rata sebesar 8,01 dengan rata-rata kadar $\mathrm{Pb}$ pada air sumur gali sebesar 0,0086 mg/l. Nilai $\mathrm{pH}$ terendah terletak pada sampel ASG 1 dan ASG 3 atau berada pada sebelum titik pencemaran yaitu sebesar 7,7 dan yang tertinggi terletak pada sampel BSG 1 atau berada pada titik pencemaran yaitu sebesar 8,5. Menurut Permenkes No. 416 Tahun 1990 tentang persyaratan kualitas air bersih, dari 9 sampel air sumur gali kandungan $\mathrm{pH}$ tersebut masih memenuhi syarat karena kadar maksimum pH yang diperbolehkan yaitu 6,5-9,0.

Hasil uji statistik analisis bivariat menggunakan Regresi Linear didapatkan tingkat signifikan sebesar $0,193>\alpha(0,05)$, maka Ho diterima dan Ha ditolak. Jadi dapat dikatakan tidak ada hubungan $\mathrm{pH}$ dengan kadar $\mathrm{Pb}$ pada air sumur gali. Sedangkan besarnya pengaruh $\mathrm{pH}$ terhadap kadar $\mathrm{Pb}$ pada air sumur gali sebesar $10,9 \%$ dan sisanya $80,1 \%$ dijelaskan oleh sebab-sebab lain. Hal ini disebabkan karena dari 9 sumur gali tersebut kontruksi sumur gali tersebut dalam keadaan baik, dinding sumur dibuat dari tembok yang tidak tembus air dan terbuat dari pipa beton
Kelarutan logam dalam air juga dikontrol oleh $\mathrm{pH}$ air. Kenaikan $\mathrm{pH}$ air akan menurunkan kelarutan logam dalam air, karena kenaikan $\mathrm{pH}$ mengubah kestabilan dari bentuk karbonat menjadi hidroksida yang membentuk ikatan dengan partikel pada air sehingga akan mengendap membentuk lumpur. $\mathrm{pH}$ dapat mempengaruhi kandungan unsur ataupun senyawa kimia yang terdapat di perairan, diantaranya mempengaruhi kandungan logam berat yang ada di perairan. Toksisitas logam berat juga dipengaruhi oleh perubahan $\mathrm{pH}$, toksisitas dari logam berat akan meningkat bila terjadi penurunan $\mathrm{pH}$.

Menurut Hart (1982) dalam Syakti (2012) pada kondisi pH mendekati normal (7-8), kelarutan logam berat cenderung stabil dan akan berikatan dengan anion, sehingga logam berat akan membentuk kompleks organologam (bentuk logam organik dan logam anorganik) yang cenderung mengendap di dasar perairan (http://geoedukasi.ump.ac.id).

Timbal relatif dapat larut dalam air dengan $\mathrm{pH}<5$ dimana air yang bersentuhan dengan timah hitam dalam suatu periode waktu dapat mengandung $>1 \mu \mathrm{g} \mathrm{Pb} / \mathrm{l}$, sedangkan batas kandungan dalam air minum adalah $50 \mu \mathrm{g} \mathrm{Pb} / 1$.

Pengukuran Berbagai Variasi Jarak Titik Sampling dan Uji Statistik pada Air Sumur Gali Di Sekitar Sungai Rompang

Hasil pengukuran berbagai jarak titik sampling dan uji statistik pada air sumur gali di sekitar Sungai Rompang dapat dilihat pada tabel 9 dan 10 sebagai berikut :

Tabel 9 : Hasil Pengukuran Berbagai Jarak Titik Sampling pada Air Sumur Gali Di Sekitar Sungai Rompang

\begin{tabular}{ccc}
\hline Nama Sampel & $\begin{array}{c}\text { Jarak } \\
\text { (meter) }\end{array}$ & Hasil (mg/l) \\
\hline ASG 1 & 60 & 0,008 \\
ASG 2 & 83 & 0,008 \\
ASG 3 & 80 & 0,009 \\
BSG 1 & 20 & 0,009 \\
BSG 2 & 15 & 0,009 \\
BSG 3 & 5 & 0,009 \\
CSG 1 & 85 & 0,008 \\
CSG 2 & 57 & 0,009 \\
CSG 3 & 70 & 0,009 \\
\hline
\end{tabular}

Tabel 10 : Hasil Uji Statistik Berbagai Variasi Jarak dengan Kadar $\mathrm{Pb}$ pada Air Sumur Gali Di Sekitar Sungai Rompang

\begin{tabular}{llllll}
\hline $\begin{array}{l}\text { Varia } \\
\text { bel }\end{array}$ & $\begin{array}{l}\text { Signif } \\
\text { ikan }\end{array}$ & $\mathbf{R}$ & $\mathbf{R}$ & Kons \\
& & & $\begin{array}{l}\text { squar } \\
\text { tanta }\end{array}$ & \\
\hline
\end{tabular}




\begin{tabular}{|c|c|c|c|c|c|}
\hline Jarak & 0,060 & 0,556 & 0,309 & 0,009 & $-8,882 \mathrm{E}-6$ \\
\hline
\end{tabular}

menunjukan bahwa rata-rata kadar $\mathrm{Pb}$ air sumur gali di lokasi penelitian sebesar 0,0086 mg/l. Jarak sumur gali yang paling dekat dengan sumber pencemaran yaitu berjarak 5 meter dengan kadar $\mathrm{Pb}$ sebesar $0,009 \mathrm{mg} / \mathrm{l}$ dan jarak sumur gali yang paling jauh dengan sumber pencemaran yaitu berjarak 85 meter dengan kadar $\mathrm{Pb}$ sebesar 0,008 mg/l. Kadar $\mathrm{Pb}$ air sumur gali tersebut masih dibawah nilai ambang batas untuk standar menurut Permenkes No. 416 Tahun 1990 tentang persyaratan kualitas air bersih.

Sedangkan berdasarkan hasil uji analisis bivariat menggunakan Regresi Linear didapatkan tingkat signifikan sebesar $0,060>\alpha(0,05)$, maka Ho diterima dan Ha ditolak. Jadi dapat dikatakan tidak ada hubungan jarak pencemaran dengan kadar $\mathrm{Pb}$ pada air sumur gali. Sedangkan besarnya pengaruh jarak pencemaran terhadap kadar $\mathrm{Pb}$ pada air sumur gali sebesar 30,9\% dan sisanya 60,1\% dijelaskan oleh sebab-sebab lain.

Berdasarkan hasil di atas bahwa jarak tidak berpengaruh terhadap kadar $\mathrm{Pb}$ pada air sumur gali. Selain jarak diduga ada faktor lain yang mempengaruhi kadar $\mathrm{Pb}$ pada air sumur gali diantaranya adalah dipengaruhi oleh kesadahan, $\mathrm{pH}$, alkalinitas, dan kadar oksigen (Effendi, 2003). Curah hujan, debit, kondisi geografis, jenis tanah, porositas dan permeabilitas juga mempengaruhi kadar $\mathrm{Pb}$ pada air, musim dan pergerak air tanah.

Kesadahan adalah gambaran kation logam divalen (valensi dua). Kesadahan perairan berasal dari kontak air dengan tanah dan bebatuan. Kesadahan yang tinggi dapat mempengaruhi daya racun logam berat mempengaruhi daya racun logam berat, karena logam berat dalam air yang berkesahan tinggi akan membentuk senyawa kompleks yang mengendap dalam dasar perairan.

Menurut penelitian Ratnaningsih,dkk (2014), jenis tanah aluvial prositasnya sangat baik karena terdiri dari lapisan pasir dan kerikil. Akan tetapi pada lapisan ini kurang mampu menyaring air sehingga air yang mengandung limbah cair batik mudah menyebar. Pergerakan aliran air ditanah alluvial yang cenderung melambat mengakibatkan kandungan krom pada limbah cair tidak dapat masuk kedalam air sumur gali secara langsung. Oleh karena itu air sumur yang berlokasi jauh dari industri batik dimungkinkan letak sumur gali berada di bawah dari letak sumber pencemar makan bahan pencemar bersama aliran air tanah akan mengalir untuk mencapai sumur gali tersebut. Diketahui bahwa air tanah mengalir dari daerah yang memiliki tekanan lebih tinggi menuju ke daerah yang memiliki tekanan lebih rendah dan berakhir menuju laut atau sungai.

\section{KESIMPULAN}

Hasil penelitian badan air Sungai Rompang yang telah dilakukan pada tiga titik pengambilan sampel (bagian hulu, titik pencemaran dan hilir) membuktikan bahwa rata-rata suhu air $28^{\circ} \mathrm{C}, \mathrm{pH}$ 8.8 dan kadar timbal $(\mathrm{Pb})$ 0,014 mg/l.

Sedangkan untuk hasil penelitian air sumur gali dianalisis dengan menggunakan uji regresi linier sederhana dapat disimpulkan bahwa tidak ada hubungan suhu dengan kadar $\mathrm{Pb}(p=0,085), \mathrm{pH}$ dengan kadar $\mathrm{Pb}(p=0,193)$ dan jarak dengan kadar $\mathrm{Pb}(p=0,085)$.

\section{SARAN}

1. Bagi Masyarakat

a. Pengusaha batik perlu mengolah limbah cair batik sebelum dibuang ke lingkungan.

b. Sebaiknya masyarakat tidak menggunakan sumber air bersih yang tercemar timbal $(\mathrm{Pb})$.

c. Sebaiknya masyarakat pada saat membuat sumur gali, lebih memperhatikan kontruksi sumur gali, kedalaman sumur gali agar terhindar dari pencemaran akibat limbah batik.

d. Bila terjadi kenaikan kadar timbal $(\mathrm{Pb})$ pada air sumur gali, dapat dilakukan menggunakan pemanfaatan zeolit abu sekam padi.

2. Bagi Pemerintah

a. Pemerintah Desa

Sebaiknya Pemerintah Desa bersama dengan pihak industri membuat pembangunan IPAL komunal.

b. BLH (Badan Lingkungan Hidup) Sebaiknya BLH membantu Pemerintah Desa setempat dan pihak industri dalam membuat IPAL komunal yang baik agar tidak mencemari lingkungan.

c. Dinas Kesehatan (Laboratorium Kesehatan) dan Puskesmas

Sebaiknya melalukan pemantauan secara berkala minimal 1 kali dalam setahun terkait kualitas sumur gali, kualitas badan air dan kualitas limbah cair yang dibuang ke lingkungan sehingga ada kontrol dari pihak pemerintahan dan demi untuk meningkatkan derajat kesehatan masyarakat setempat.

3. Bagi Peneliti Lain 
a. Perlu dilakukan pengujian yang lebih lengkap mengenai parameter-parameter lain (Kromium, Kadmium, dll) yang berhubungan dengan pencemaran limbah batik.

b. Menambahkan variabel faktor-faktor lain yang berkaitan dengan terjadinya pencemaran logam berat timbal $(\mathrm{Pb})$ ke air sumur gali dan air sungai seperti kadar oksigen, kesadahan, alkalinitas.

\section{UCAPAN TERIMA KASIH}

Terima kasih disampaikan kepada Jurusan Kesehatan Lingkungan Politeknik Kesehatan Kemenkes Semarang yang telah mendanai keberlangsungan jurnal ini.

\section{DAFTAR PUSTAKA}

Arief Happy R, dkk., 2012, "Distribusi kandungan Logam Berat Pb dan Cd pada Kolom Air dan Sedimen Daerah Aliran Sungai Citarum Hulu", at http://jurnal.unpad.ac.id diakses 10 Februari 2016

Aryono Sarjono, 2009, "Analisis Kandungan Logam Berat Cd, Pb, dan Hg pada Air dan Sedimen di Perairan Kamal Muara Jakarta Utara", at http://repository.ipb.ac.id diakses tanggal 10 Februari 2016

Budiman Chandra, 2005, Pengantar Kesehatan Lingkungan, Jakarta: Buku Kedokteran EGC

Dantje T, dkk., 2015, Toksikologi Lingkungan, Yogyakarta : ANDI

Darmono, 1995, Logam dalam Sistem Biologi Makhluk Hidup, Jakarta: UI-Press

Darmono, 2006, Lingkungan Hidup dan Pencemaran (Hubungannya dengan Toksikologi Senyawa Logam),Jakarta: UI-Press

Dirjen PPM \& PL, 1994, Pedoman Pengendalian Dampak Pencemaran Limbah Industri Terhadap Kesehatan, Jakarta: Depkes RI

Esti Nugraheni, 2015, "Efektivitas Perendaman AKtivator NaOH Arang Serbuk Gergaji dalam Menurunkan Kadar Logam Berat Timbal Limbah Cair Batik (Studi Kasus Tjokro, Bakaran Pati)", at http://www.eprints.undip.ac.id diakses tanggal 23 Desember 2015

Frank C. Lu, 1995, Toksikologi Dasar Asas, Organ, Sasaran, dan Penilaian Risiko, Jakarta: UIPress

G. Alaerts \& Sri Sumestri Santika, 1984, Metode Penelitian Air, Surabaya : Usaha Nasional

Hefni Effendi, 2003, Telaah Kualitas Air, Yogyakarta: Kanisius

Heryando Palar, 1994, Pencemaran dan Toksikologi Logam Berat, Jakarta: Rineka Cipta
I Hartati, dkk., 2011, "Potensi Xanthate Pulpa Kopi sebagai Adsorben pada Pemisahan Ion Timbal dari Limbah Industri Batik", at http://www.publikasiilmiah.unwahas.ac.id diakses tanggal 23 Desember 2015

Juli Soemirat, 2003, Toksikologi LIngkungan, Yogyakarta: Gadjah Mada University Press

Kodoatie Robert,J\&Sjarief,R., 2008, Pengelolaan Sumber Daya Air Terpadu, Yogyakarta: ANDI

Kodoatie Robert, J., 2012, Tata Ruang Air Tanah, Yogyakarta:ANDI

Mukono, H.J., 2000, Prinsip Dasar Kesehatan Lingkungan, Surabaya: Airlangga University Press

Marsono, 2009, "Faktor-Faktor yang Berhubungan dengan Kualitas Bakteriologi Air Sumur Gali Di Permukiman", at http://eprints.undip.ac.id diakses tanggal 10 Juni 2016

Nusa Idaman S, 2002, Kualitas Air Minum dan Dampaknya Terhadap Kesehatan, Jakarta: Pusat Pengkajian dan Penerapan Teknologi Lingkungan

Nusa Idaman S, dkk., 2002, Aplikasi Teknologi Biofilter untuk Pengolahan, Jakarta: Pusat Pengkajian dan Penerapan Teknologi Lingkungan

Nusa Idaman S, 2008, Pengolahan Air Limbah Domestik di DKI Jakarta (Tinjauan Permasalahan, Strategi, dan Teknologi Pengolahan), Jakarta: Pusat Teknologi Lingkungan

Nusa Idaman S, 2008, Teknologi Pengolahan Air Minum (Teori dan Pengalaman Praktis), Jakarta: Pusat Teknologi Lingkungan

Perdana Gintings, 1992, Mencegah dan Mengendalikan Pencemaran Industri, Jakarta: Pustaka Sinar Harapan

Rafikhul Rizza, 2013, "Hubungan Antara Kondisi Fisik Sumur Gali dengan Kadar Nitrit Air Sumur Gali Di Sekitar Sungai Tempat Pembuangan Limbah Cair Batik", at http://journal.unnes.ac.id/artikel_sju/pdf/ujp h/3029/2802 diakses tanggal 31 Mei 2016

Ratnaningtyas, dkk., "Kandungan Krom Pada Limbah Cair Batik dan Air Sumur Gali Di Sekitar Industri Batik UD Bintang Timur" at http://repository.unej.ac.id diakses tanggal 15 Juni 2016

Santi Susiloputri \& Savitri Nur Farida Q, 2009, "Pemanfaatan Air Tanah untuk Memenuhi Air irigasi Di Kabupaten Kudus Jawa Tengah”, at http://eprints.undip.ac.id>1965_CHAPTER_II diakses tanggal 9 Februari 2016

Setiyono,dkk., 2004, Pedoman Teknis Pengelolaan Limbah Industri Kecil, Jakarta: Kementerian Lingkungan Hidup 
Soedarto, 2013, Lingkungan dan kesehatan, Jakarta: CV Sagung Seto

Soeparman \& Suparmin, 2002, Pembuangan Tinja \& Limbah Cair, Jakarta: Penerbit Buku Kedokteran EGC

Srikandi Fardiaz., 1992, Polusi Air dan Udara, Yogyakarta: Kanisius

Suwarsito \& Esti Sarjanti, 2014, "Analisa Spasial Pencemaran Logam Berat Pada Sedimen dan Biota Air Di Muara Sungai Serayu Kabupaten Cilacap", at http://geoedukasi.ump.ac.id/ diakses tanggal 30 Mei 2016

Suyono,dkk., 2011, Ilmu Kesehatan Masyarakat dalam Konteks Kesehatan Lingkungan, Jakarta: Penerbit Buku Kedokteran EGC

Suyono S \& Kensaku T, 1977, Hidrologi untuk Pengairan, Jakarta: PT.Pradnya Paramita Totok Sutrisno, dkk., 2010, Teknologi Penyediaan Air Bersih, Jakarta: Rineka Cipta

Tri Muniarti, dkk, 2015, "Pengelolaan Limbah Cair Industri Batik dengan Metode Elektrolisis sebagai Upaya Penurunan Tingkat Konsentrasi Logam Berat Di Sungai Jenes, Laweyan, Surakarta", https://eprints.uns.ac.id/18136/2/BAB_I.pdf diakses tanggal 24 Februari 2016

Watini, 2008, Pengaruh Waktu Kontak Eceng Gondok (Eichorrnia crassipes) terhadap Penurunan Kadar Kadmium (Cd) dan Kromium (Cr) pada Air Limbah Industri Batik (Home Industri Batik di Desa Sokaraja Lor), Purwokerto: Universitas Jendral Soedirman

Wisnu Arya W, 1995, Dampak Pencemaran Lingkungan, Yogyakarta: Andi Offset 